DOI: 10.20472/IAC.2020.054.022

\author{
AVRAM ROXANA - LOREDANA \\ Faculty of Economics and Business Administration, West University of Timisoara, Romania
}

NICOLESCU ANA - CRISTINA

Faculty of Economics and Business Administration, West University of Timisoara, Romania

BUGLEA ALEXANDRU

Faculty of Economics and Business Administration, West University of Timisoara, Romania

\title{
THE NEW PERSPECTIVES OF CORPORATE SOCIAL RESPONSIBILITY IN THE POST-CORONA ECONOMY
}

\begin{abstract}
:
The recent socio-economic evolutions generated by the Covid-19 is showing tectonic shifts in every country economic structure, with entire sectors being affected with unprecedented contractions. The economic cost of the pandemic is unprecedented, the most important international financial institutions placing the following recession to World War 2 levels. However, in times of great catastrophes, natural or manmade, there has always been a time of great shifts in the social behavior, determined by the solidarity between society, decision-makers and corporations. Our study is focusing in shifts of the Corporate Social Responsibility and the behavior of corporate management, characterized by temporarily abandoning the path of profit maximization and reorientation towards supporting the community and the decision makers, in the fight against the effects of the pandemic. In addition, our study tries to examine the alteration of social behavior, from an entrepreneurial orientated society, in the pre-pandemic economy, towards a more security driven behavior, in terms of food, job and health security. The social-economic implications of the changes could bring changes in the behavioral economics that seemed impossible only a few months ago.
\end{abstract}

\section{Keywords:}

Corporate social responsibility, Corporate governance, Performance, Socio-economic evolutions

JEL Classification: G30, H12, M20 


\section{Introduction}

The pandemic caused by Covid-19 is a classic case of exogenous shock that affects both the health field and the economy, creating serious disruptions at the macroeconomic and sectoral level. This outbreak was triggered in December 2019 in the Chinese city of Wuhan and has continued to spread around the world with astonishing speed. At the time of this article, the World Health Organization announced that 8.7 million cases had been registered worldwide since the beginning of the pandemic, most of them in North and South America, and in Europe. Unfortunately, the number of cases being shows an upward trend, considering that a second wave of this pandemic could follow.

Thus, against the background of quarantine and social distancing measures imposed by the authorities, this epidemiological shock generates simultaneously contraction effects of significant magnitudes, both at the level of demand and also, at the level of supply. Uncertainties regarding the spread of the virus evolution or the speed of subsequent recovery of the economy are still at considerable levels, especially in the context of a possible second wave of the epidemic or through the background of epidemic's recurrence.

A simple economic perspective on the effects of COVID-19 calls into question the aggregate demand versus the aggregate supply, respectively which of them is most affected by the shock. Several authors (Guerrieri, Lorenzoni, Straub Werning, 2020) expressed skepticism about the results of policies meant to stimulate aggregate demand through shortages in terms of aggregate supply, considering that the public policy should focus, at the beginning, only in terms of social assistance measures.

At the same time, a number of authors believe that all these measures are meant to reduce the recessionary curve's amplitude (Gourinchas, 2020), in their absence, the recovery taking longer and having more burdensome socio-economic effects.

The macroeconomic problems generated by the COVID-19 pandemic are studied by a number of authors, including the authors Baldwin and Weder di Mauro (2020) who came up with a series of public policy proposals. Also, the authors Fornaro and Wolf studied the pandemic from the perspective of the negative shock of the productivity's growth rate. They also takeinto consideration endogenous technological changes and stagnation traps in their research.

Studies on the macroeconomic effects of the SARS outbreak in 2003 identified significant effects on the economies by large reductions in consumption of goods and various services, an increase in operating costs of companies and revaluation of country risks reflected in increasing risk premiums (Lee, McKibbin, 2004). Despite a relatively small number of cases and deaths, the overall costs of the SARS epidemic were significant and not limited to the countries directly affected. As a result, in the current situation, in which the COVID-19 pandemic has affected the whole globe, we ask ourselves what the real costs of the pandemic will be and to what extent they will affect us.

\section{Implications of COVID-19 Pandemic}

All economic studies published recently (March - June 2020) reach a similar conclusion, namely that the COVID-19 pandemic will bring a strong economic recession. According to Eurostat, the latest economic forecasts for spring 2020 show that the euro area economy will register a record contraction of $7.4 \%$ in 2020 , with a recovery of around $6 \%$ next year. Basically, 
the impact will be significantly greater than duringthe 2009 recession and these forecasts may not be final and get even gloomier, depending on the second wave of the pandemic that might occur. The shock was felt symmetrically by all European Union states as the pandemic has affected all states, but the recovery capacity in 2021 will vary from country to country, depending on the ability of each state to manage the situation and take the best economic measures.

Unfortunately, the first side effects began to be observed starting with February - March, depinding on how quickly the virus has made its presence felt in each country: companies began to have difficulties in executing contracts, some employers had to send their employees into technical unemployment or shorten their work schedule, and some of them even needed to close.

Also, one of the sectors severely affected by the pandemic is tourism, with different, but important, shares in the economy of EU Member States. Europe accounts for half of the world's tourist destinations, and for some countries that are dependent on tourism, such as Spain, Italy, France and Greece, the situation is extremely difficult. Thus, according to the European Commission, it is estimated that revenues will decrease by about $50 \%$ for hotels and restaurants, $70 \%$ for travel agencies and $90 \%$ for airlines and cruise operators. According to the United Nations World Tourism Organization, on April 20, 2020, 100\% of the world's tourist destinations adopted temporary restriction measures in response to the COVID-19 pandemic.

In this context, states around the world have been forced to come up with concrete measures to help companies and ensure the well-being of citizens in these difficult times of pandemic.

\section{Measures Plan on EU Member States}

Support programs are being implemented by national governments in all European countries, as well as at the level of supranational institutions.

The dimension of programs implemented so far in Romania, estimated at approx. $3 \%$ of GDP, is significantly below that of similar actions in other countries of the region or in the EU. Most countries have taken measures such as: moratoriums, loan guarantees, measures to support the labor market (technical unemployment or reduced working time), fiscal facilities (postponements, reductions, exemptions).

From the budgetary discipline perspective, the European Commission proposed the activation of the general derogation clause in the Stability and Growth Pact (SGP), calling on the Council of the European Union to approve this measure as soon as possible. Thus, the increase in budget spending and the fall in GDP will contribute to record substantially higher budget deficits. The Commission considers the COVID-19 pandemic to be a major shock for the European and global economies.

From a monetary policy point of view, the European Central Bank has launched an extensive quantitative easing process aimed at the temporary purchase of assets worth $€ 750$ billion, to counteract the serious risks to the monetary policy transmission mechanism and the outlook for the euro area presented by the spread of COVID-19. These measures have also been coordinated by the FED.

In Table no. 1 we presented the main measures taken by some of the EU Member States (Germany, Italy, France, Bulgaria, Hungary, Greece and Romania) in respect of guarantees or state loans for companies, during the pandemic COVID-19. 
Table no. 1 State Guarantees or Loans for Companies in the EU member states

\begin{tabular}{|c|c|}
\hline $\begin{array}{l}\text { Member } \\
\text { State }\end{array}$ & State Guarantees or Loans for Companies \\
\hline Germany & $\begin{array}{l}\text { 1. } € 600 \text { billion rescue fund for large companies, of which: } \\
\text { a) } € \mathbf{4 0 0} \text { billion government guarantees for lending to companies - guarantees } \\
\text { estimated at zero cost; } \\
\text { b) } € 100 \text { billion State Participations in companies affected by the crisis, which opt } \\
\text { for this intervention Ex. Lufthansa; } \\
\text { c) } € \mathbf{1 0 0} \text { billion Refinancing Funds through the state bank KfW to ensure liquidity } \\
\text { in companies. } \\
\text { 2. Special Program for SMEs - accessed through own bank } \\
\text { a) } 90 \% \text { guarantee for equipment and means of production credits, the credit } \\
\text { interest being between } 1 \% \text { and } 1.46 \% / y e a r ; \\
\text { b) } 80 \% \text { guarantee for large enterprises, credit interest being between } 2 \% \text { and } \\
2.12 \% \text { / year. }\end{array}$ \\
\hline Italy & $\begin{array}{l}\text { 1. State guarantees for access to loans by SMEs and freelancers - mortgage } \\
\text { loans with interest } 0 \text { for a period of } 15 \text { years to pay off bank debt. } \\
2 \text {. An increase by } € 350 \text { million of the funds intended to support export } \\
\text { programs in } 2020 \text {, by granting loans with subsidized rates. Implementation of } \\
\text { a co-insurance system according to which the commitments deriving from } \\
\text { the insurance activity of SACE are taken over by the state in proportion of } \\
90 \% \text { and only } 10 \% \text { by the company. } \\
3 . \text { Allocation of } € 500 \text { million to save Alitalia by creating a new } 100 \% \text { public } \\
\text { company - Newco - which would lease Alitalia's activities. } \\
4 \text {. State guarantees of around } € 200 \text { billion, through SACE Simest, in favor of } \\
\text { banks granting loans to companies, in any form. } \\
\text { The guarantee will cover between } 70 \% \text { and } 90 \% \text { of the amount financed, } \\
\text { depending on the size of the company and is subject to a number of conditions } \\
\text { such as suspension of the company's dividends for the next twelve months and } \\
\text { support for production costs in Italy. } \\
\text { The loans will be intended for: } \\
\text { - companies with less than } 5,000 \text { employees and a turnover of less than EUR } 1.5 \\
\text { billion obtain a guarantee of up to } 90 \% \text { of the amount of financing requested, } \\
\text { through a simplified procedure; } \\
\text { - } 80 \% \text { guarantee for companies with more than } 5,000 \text { employees and a turnover } \\
\text { between } 1.5 \text { and } 5 \text { billion Euros and a } 70 \% \text { guarantee for companies with a } \\
\text { turnover of over } 5 \text { billion Euros; } \\
\text { For small and medium-sized enterprises, including the authorized natural person, } \\
\text { an additional } € 30 \text { billion is allocated through the SACE guarantor, but provided } \\
\text { that they exhaust their loans through the central guarantee fund. }\end{array}$ \\
\hline France & $\begin{array}{l}\text { 1. State Guarantee Fund, worth up to } € 300 \text { billion, for all new loans granted } \\
\text { by credit institutions between March } 16 \text { and December } 31,2020 \text { to all } \\
\text { companies registered in France. }\end{array}$ \\
\hline
\end{tabular}




\begin{tabular}{|c|c|}
\hline & $\begin{array}{l}\text { a) Loans can cover up to } 25 \% \text { of the company's annual turnover. } \\
\text { b) The duration of the loan will be } 6 \text { years. } \\
\text { c) The state guarantee will cover } 90 \% \text { of the loan amount for small enterprises, } \\
\text { SMEs and medium-sized enterprises. } \\
\text { d) The interest will be } 0.25 \% \text { / year for SMEs and } 0.50 \% \text { / year for medium-sized } \\
\text { enterprises and large companies. } \\
2 \text {. Solidarity Fund - over } € 7 \text { billion, will finance two types of companies: } \\
\text { a) companies whose activity has been closed } \\
\text { b) very small companies. } \\
\text { They receive directly } € 1,500 \text { if they meet the following conditions: they lost } 70 \% \text { of } \\
\text { turnover between March } 2019 \text { and March } 2020 \text { and they had a turnover of less } \\
\text { than } € 1 \text { million. } \\
3 . € 2 \text { billion Allocation for the short-term export credit reinsurance system. It } \\
\text { involves doubling the ceiling on outstanding amounts that can be guaranteed by } \\
\text { the state and will be extended to a larger number of destination countries. } \\
4 \text { SMEs program of repayable advances - value } 500 \text { mil. } € \\
5 \text {. Program of loans granted directly by the state to intermediate size } \\
\text { companies - value } 1 \text { billion } € \\
6 \text {. } € 20 \text { billion for state participations in strategic companies affected by the } \\
\text { crisis (Ex. Air France-KLM) }\end{array}$ \\
\hline Bulgaria & $\begin{array}{l}\text { 1. } € 250 \text { million support scheme for companies affected by the crisis, to cover } \\
\text { the rates contracted for carrying out the activity. The funds will be transferred to } \\
\text { the Bulgarian Development Bank, which will provide guarantees to } \\
\text { commercial banks to which private companies have loans. The bank will be able } \\
\text { to temporarily take over stakes in the affected companies, with the option of } \\
\text { buyback. }\end{array}$ \\
\hline Hungary & $\begin{array}{l}\text { 1. Aid scheme to support SMEs in temporary financial difficulty as a result of } \\
\text { exceptional and unpredictable events. } \\
\text { 2. The Hungarian Tourism Agency has allocated } € 2.8 \text { million to cover } \\
\text { damage in the tourism sector. }\end{array}$ \\
\hline Greece & $\begin{array}{l}\text { 1. Guarantee scheme for bank loans to SMEs amounting to } € 6 \text { billion } \\
\text { 2. The interest rate is subsidized for the loans of companies affected by the } \\
\text { crisis if they have paid all their debts up to date. } \\
\text { 3. Financing scheme for companies with a total value of } € 1 \text { billion, by } \\
\text { granting a repayable advance necessary for current business activities and } \\
\text { coverage of salary costs. }\end{array}$ \\
\hline Romania & $\begin{array}{l}\text { 1. State aid scheme to support the activity of SMEs - SME Invest according to } \\
\text { which guarantees of } 80 \% \text { or } 90 \% \text { of the value of financing for investments } \\
\text { and financing of working capital are granted, guaranteed by the state in a } \\
\text { maximum percentage of } 90 \% \text { granted a micro or small enterprise. } \\
\text { 2. Similar facilities for large companies. }\end{array}$ \\
\hline
\end{tabular}

Source: own interpretation

The epidemic caused by the new virus has a significant economic impact. As it appears from table no. 1, several Member States have announced support measures for citizens or 
businesses. For the most part, the measures taken in each country are similar, but the funds granted depend on the financial situation of each country of by the funds allocated from EU.

In Table no. 2 we presented the main measures taken by some of the EU Member States (Germany, Italy, France, Bulgaria, Hungary, Greece and Romania) in respect of wage Subsidies for the unemployed / parents caring for minor children, during the pandemic COVID-19.

Table no. 2 Wage Subsidies for the unemployed / parents caring for minor children in the EU Member States

\begin{tabular}{|c|c|}
\hline$\frac{\text { Member }}{\text { State }}$ & Wage Subsidies for the unemployed / parents caring for minor children \\
\hline Germany & $\begin{array}{l}\text { 1. Payment of } 60 \% \text { of employers' net salary for employees who are temporarily } \\
\text { unemployed and of social security contributions } \\
\text { 2. Compensation of } 67 \% \text { of the salary for parents of children under the age of } \\
\text { twelve, if they cannot work due to childcare. }\end{array}$ \\
\hline Italy & $\begin{array}{l}\text { 1. Allowance of } € 500 \text { / month, for up to } 3 \text { months for employees - liberal } \\
\text { professions in the most affected municipalities at the end of February. } \\
\text { 2. Granting a } € 600 \text { allowance to seasonal workers in the field of tourism and } \\
\text { agriculture in March } \\
3 . € 1.3 \text { billion fund to cover expenses related to the payment of technical } \\
\text { unemployment in derogation - granted for a maximum of } 9 \text { weeks to private } \\
\text { employers, including those in agriculture, fisheries, volunteering, NGOs and } \\
\text { civically recognized religious institutions. Companies that can benefit from } \\
\text { ordinary technical unemployment, employers of housekeepers and workers } \\
\text { employed after } 23.02 .2020 \text { are excluded. }\end{array}$ \\
\hline France & $\begin{array}{l}\text { 1. Payment for } 2 \text { months of } 100 \% \text { of the partial unemployment, within the limit } \\
\text { of } 4 \text { and a half minimum wages (total value est. } 8.5 \text { billion } € \text { ) } \\
2 \text {. Mobilizing the financial reserves of supplementary pension plan for the self- } \\
\text { employed, amounting to } € 1 \text { billion, in order to finance an exceptional aid. } \\
\text { The aid corresponds to the value of additional contributions for pensions, } \\
\text { paid by artisans and traders, based on their income in } 2018 \text { and can reach } € \\
1,250 \text {. }\end{array}$ \\
\hline Bulgaria & $\begin{array}{l}\text { 1. Payment of } 60 \% \text { of the salary of employees in danger of dismissal, the } \\
\text { remaining } 40 \% \text { being paid by the employer, the criteria for granting this support } \\
\text { will be developed by the Bulgarian government. }\end{array}$ \\
\hline Hungary & $\begin{array}{l}\text { 1. Kurzarbeit State Aid scheme to subsidize } 70 \% \text { of salaries for employees in } \\
\text { the private sector, for companies that, due to the decree of the state of } \\
\text { emergency, reduce working hours between } 30 \% \text { and } 50 \% \text { of the initial time. }\end{array}$ \\
\hline Greece & $\begin{array}{l}\text { 1. Between March } 15 \text { and April } 30 \text { of this year, employees with employment } \\
\text { contracts and authorized natural persons, temporarily suspended, will receive } \\
\text { a compensation of } € \mathbf{8 0 0} \text { at the beginning of April. } \\
\text { 2. Employers have the obligation to maintain the same number of employees after } \\
\text { the termination of the suspension, for a period equal to the duration of the } \\
\text { suspension of employment contracts. } \\
\text { 3. It is forbidden by law for employers and enterprises to dismiss staff or employees, }\end{array}$ \\
\hline
\end{tabular}




\begin{tabular}{|c|c|}
\hline & $\begin{array}{l}\text { tarting from March } 18 \text { until the date of cessation of measures taken by the } \\
\text { overnment to combat the Covid- } 19 \text { pandemic; in case of dismissal, based on the } \\
\text { ecree, they are considered null and void. }\end{array}$ \\
\hline Romania & $\begin{array}{l}\text { 1. Payment of } 75 \% \text { of the average gross salary for parents with children under } \\
12 \text { years of age, from the beginning of the state of emergency until the end of } \\
\text { school (June } \\
\text { 2. Granting technical unemployment in the amount of } 75 \% \text { of the basic salary } \\
\text { corresponding to the job, but not more than } 4,072 \text { lei per month for employees } \\
\text { in areas where restrictions have been imposed and where the employer has } \\
\text { reduced totally or temporarily interrupted the activity. }\end{array}$ \\
\hline
\end{tabular}

Source: own interpretation

The European Commission has adopted a temporary framework to allow Member States to use all the flexibility provided by State aid rules to support the economy in the context of COVID-19. As it appears from Table no. 2, each state has granted technical unemployment or a similar measure in order to protect the employees and also, to help the companies to survive. Also, parents were allowed to stay at home with their children in the period when the schools were closed and they received financial support in this period.

In Table no. 3 we presented the main measures taken by some of the EU Member States (Germany, Italy, France, Bulgaria, Hungary, Greece and Romania) in respect of Tax Exemptions, Payment of Social Contributions Exemptions / subsidies, during the pandemic COVID-19.

Table no. 3 Tax Exemptions, Payment of Social Contributions Exemptions / subsidies

\begin{tabular}{|c|c|}
\hline $\begin{array}{l}\text { Member } \\
\text { State }\end{array}$ & Tax Exemptions, Payment of Social Contributions Exemptions / subsidies \\
\hline Germany & $\begin{array}{l}\text { 1. The state bears the payment of social contributions for the temporarily } \\
\text { unemployed } \\
\text { 2. All payments of taxes to the state of companies in the automotive } \\
\text { industry were postponed without penalties and interest until the due date of } \\
\text { June. The facility was not part of the intervention package offered by the state } \\
\text { and was obtained by the German Automobile Industry Association through } \\
\text { parallel negotiations. }\end{array}$ \\
\hline Italy & $\begin{array}{l}\text { 1. Suspension of taxes and social assistance contributions payment for } \\
\text { companies in the affected sectorswith withholding at source. } \\
\text { 2. Postponement of tax obligations of workers and companies, in particular } \\
\text { the payment of VAT and the payment of contributions for April and May. } \\
\text { 3. Postponement of tax and social security payments for the tourism sector } \\
\text { until May } 31 \text { this year } \\
\text { 4. Measures to ensure the continuity of companies' activities during the } \\
\text { state of emergency, especially those that were in balance before the crisis and } \\
\text { had a regular business continuity perspective: } \\
\text { - measures regarding the deactivation of the company's dissolution causes due }\end{array}$ \\
\hline
\end{tabular}




\begin{tabular}{|c|c|}
\hline & $\begin{array}{l}\text { to the reduction or loss of the share capital; } \\
\text { - Other measures relating to insolvency or insolvency proceedings. }\end{array}$ \\
\hline France & $\begin{array}{l}\text { 1. Postponement of the payment of fiscal and social taxes for March } \\
\text { (estimated value } 32 \text { billion } € \text { ) }\end{array}$ \\
\hline Bulgaria & There are no measures related to tax exemptions. \\
\hline Hungary & $\begin{array}{l}\text { 1. Exemption from paying social security contributions for affected } \\
\text { companies until June } \mathbf{3 0 .} \\
\text { In addition, these contributions will be considerably reduced - contributions to the } \\
\text { pension system will no longer be paid, only health contributions. }\end{array}$ \\
\hline Greece & $\begin{array}{l}\text { 1. Decrease of VAT to } 6 \% \text { (from } 24 \% \text { ), for the whole period of } 2020 \text { for ethyl } \\
\text { alcohol used in the production of antiseptics and for all hygiene and } \\
\text { medical protection products. } \\
\text { 2. Suspension of VAT payment, payable at the end of March, for } 4 \text { months, } \\
\text { for sectors and activities in areas where the activity is suspended by } \\
\text { government order for more than } 10 \text { days. } \\
\text { 3. Suspension of the payment of tax debts and previously certified } \\
\text { receivables, payable at the end of March, for a period of } 4 \text { months, for } \\
\text { sectors and activities in areas where the activity is suspended by } \\
\text { government order for more than } 10 \text { days. } \\
\text { 4. The state supports social security contributions and health contributions } \\
\text { payment for temporarily suspended employees. }\end{array}$ \\
\hline Romania & $\begin{array}{l}\text { 1. Bonus for the advance payment of the profit tax / income tax of micro- } \\
\text { enterprises. } \\
\text { 2. Postponement of customs duty on importers of test kits, medicinal } \\
\text { products and protective equipment for COVID-19. } \\
\text { 3. Postponement from } 31 \text { March to } 30 \text { June of the deadline for payment of } \\
\text { taxes: building tax, land tax, respectively the tax on means of transport, as well } \\
\text { as the deadline for granting the advance payment bonus. } \\
\text { 4. Change in the amount of advance payments for taxpayers who file annual } \\
\text { income tax. Taxpayers can make partial payments due in } 2020 \text { at the amount of } \\
\text { profit calculated for the first quarter of this year. }\end{array}$ \\
\hline
\end{tabular}

Source: own interpretation

In addition to the information provided in Table no. 3, the European Commission grants an exemption from customs duties and VAT on imports of medical equipment from non-EU countries.

In Table no. 4 we presented the main measures taken by some of the EU Member States (Germany, Italy, France, Bulgaria, Hungary, Greece and Romania) in respect of postponement of utilities payment/price capping, during the pandemic COVID-19. 
Table no. 4 Postponement of utilities payment/price capping

\begin{tabular}{|c|c|}
\hline$\frac{\text { Member }}{\text { State }}$ & Postponement of utilities payment/price capping \\
\hline Germany & There are no measures related to postponement of utilities. \\
\hline Italy & $\begin{array}{l}\text { 1. Suspension for } 2 \text { months of the electricity, gas, water and waste bills' } \\
\text { payment in the most affected municipalities until the end of February. }\end{array}$ \\
\hline France & $\begin{array}{l}\text { 1. Suspension and rescheduling without penalties of electricity, gas, water } \\
\text { and rent bills for SMEs. } \\
\text { 2. Postponement of the execution of public procurement contracts without } \\
\text { penalties. }\end{array}$ \\
\hline Bulgaria & $\begin{array}{l}\text { 1. Extending deadlines for payment of utility bills. } \\
2 . \text { Imposition of limits on the sale of goods and services (average price of } \\
\text { the last } 3 \text { months prior to the declaration of emergency / limit of } 20 \% \text { for } \\
\text { goods and services for which no such evidence is available), being provided } \\
\text { substantial financial penalties for violation of these provisions. }\end{array}$ \\
\hline Hungary & $\begin{array}{l}\text { 1. Suspension of the payment of installments for all loans contracted by } \\
\text { companies and private individuals until the end of the year. } \\
\text { 2. It is forbidden by law to increase rents or terminate rental contracts. }\end{array}$ \\
\hline Greece & $\begin{array}{l}\text { 1. Suspension of repayment of loan installments for all debtors with active } \\
\text { accounts, as well as a suspension of three months in the case of } \\
\text { temporarily suspended employees. } \\
\text { 2. The repayment of non-performing loans with maturity between 03.03- } \\
30.04 .2020 \text { was extended until } 31.08 .2020 \text {, as well as in the case of debtors } \\
\text { registered in the installment repayment schemes. } \\
\text { In all these situations, extending the payment term will not lead to interest. }\end{array}$ \\
\hline Romania & $\begin{array}{l}\text { 1. Suspension until the end of the year of the payment of installments for } \\
\text { mortgages and personal loans contracted by the individual and at the } \\
\text { request of the debtors. } \\
\text { 2. Postponement of the payment of rents and utilities for small and medium- } \\
\text { sized enterprises during the state of emergency. }\end{array}$ \\
\hline
\end{tabular}
Source: own interpretation

As we can see from the tables above, the states affected by the COVID-19 pandemic are taking unprecedented measures to mitigate the effects that are still difficult to quantify, both in terms of population and, especially, in the global economy. To help companies overcome the difficulties created by the new state of affairs, most states have announced measures including in the tax area, most aimed at delaying the payment of taxes, especially those due to employees, but also exemptions from taxes or penalties in certain situations. At the forefront are decisions aimed at employees, including flexibility of working hours and conditions, with a focus on remote work, and facilities for paying social security contributions for employers. 
In the United States, the authorities have resorted to the already classic recipe to finance the economy, respectively reduced the interest rate of monetary policy, in two steps, to almost zero, and launched an extensive program of quantitative easing of 700 billion dollars.

The comparative image of support schemes in Romania compared to other countries in the region, although understandable at least regarding the budgetary impact measures (above the line) in terms of limited fiscal space, raises concerns about the long-term economic and social effects, including the competitiveness of Romanian economy at regional and European level.

In Romania, the main Program initiated is SME Invest, a scheme meant to guarantee loans to SMEs, with virtually no immediate budgetary impact, which has the potential to support a large number of companies and also contributes to further the lending by the banking sector.

The SME Invest program is an essential component in the mix of measures to support and restart the economy. Evaluating the program on the three criteria set out above, we note that the aim is to delegate the distribution to a market mechanism, by using the banking system for the economic analysis of projects, and the most important practical aspect remains the speed of implementation and accessibility.

Regarding the labor market, the main problem in the next period seems to be that of unemployment. Many companies have stopped or reduced their activity during the pandemic and, although they have benefited from technical unemployment subsidies, they will have difficulties in the next period due to the reduction of domestic demand. In order for these companies to be able to keep jobs and possibly create new ones, labor legislation needs to be made more flexible.

Some of these companies have negotiated directly with employees the reduction of their working hours and, implicitly, their wages, but this operation has certain legal limitations, as working hours can only be reduced from five days a week to four days, only in certain situations, and for periods not exceeding 30 working days. These limitations compel employers to take dismissal measures if the level of activity has been reduced.

In order to encourage the preservation of employment contracts, it is necessary to amend the legislation on part-time work, by orienting subsidies from the state towards:

a) partial support of the wages for the affected employees;

b) encouraging the creation of new jobs;

c) making the legislation more flexible, in the sense of allowing the use of reduced / flexible work programs.

Grants can be allocated to severely affected and / or strategic sectors, to disadvantaged regions or to large employers affected by the crisis. For this purpose, Romania can attract funds through the SURE scheme implemented at the level of European Union.

\section{European Union Recovery Plan}

European Union prepares significant investments to support citizens and businesses. Thus, on May 27, the European Commission presented to the Parliament a plan to stimulate the economy worth 750 billion Euros, to which will be added a proposal to revise the budget for the period 2021-2027.

"Next Generation EU" is the name of the EU's $€ 750$ billion economic recovery plan, which aims to repair the damage caused by the pandemic and invest in an ecological, digital and social Union. Specifically, the European Commission is going to borrow money from the financial markets at lower costs, thus using its good credit rating. The amount of $€ 500$ billionwill be 
distributed in the form of grants to achieve the EU's goals of digital transformation and climate neutrality, and social and employment support will also be provided as well. The other amount of $€ 250$ billion will be available for EU member states in the form of loans. Thus, the role of European Union as a world leader will be strongly strengthened. According to European Commission proposal, Romania will receive through "Next Generation EU" a total of $€ 31.206$ bilion, splitted as follows: 19.62 bilion are in form of grants and 11.58 bilion in the form of loans. Therefore, Romania is, as the total allocated amount, the sixth country in the EU, after Italy which receives 172 bilion, Spain 140 bilion, Poland 64 bilion, France 39 bilion and Greece 32 bilion.

As mentioned above, some companies needed to suspend their work or reduce the number of employees. In order to prevent employees and the self-employed from losing their jobs, the European Union is coming to their aid with a new measure, the "SURE" plan Temporary support for mitigating unemployment risks in an emergency status. Like the "Next Generation EU" plan, the "SURE" plan is part of a set of EU measures to help Member States fight the pandemic. Specifically, the European Union will provide the 27 Member States with up to $€ 100$ billion to support part-time unemployment programs, to help maintain jobs and employee incomes, and to help companies stay afloat. This support will also benefit farmers, fishermen and the persons most disadvantaged.

\section{Conclusions}

We note that in most European countries the mix of fiscal and monetary policies has been uniform and convergent, with measures aimed primarily at employment and ensuring liquidity in the economy.

Thus, almost all Member States used similar instruments aimed at subsidizing wages, guaranteeing loans, postponing taxes and fees and, on the monetary side, lowering the reference interest rates to levels close to 0 (Hungary, Poland, Czech Republic). However, the public policy instrument was used almost entirely, leaving the fiscal and monetary maneuver space almost exhausted in the face of future shocks. The record budget deficits to be recorded by the end of the year represent a definite cost for maintaining employment and the survival of companies. However, it can be observed that, under the influence of an election year in most European countries, we are all witnessing and contributing to the outsourcing of the profits of private companies and the socialization of their losses.

It can be noted that European countries provide significant sums to support companies in difficulty and, in addition, other measures aimed at minimizing the risk of an economic crisis (deferral of payment of taxes, non-collection of interest and late fees, temporary tax reductions, measures for the most affected sectors, technical unemployment).

Although, at this point, the most important thing is to be healthy, we must not ignore the fact that this pandemic will affect not only the physical aspect but also the morale of society. Therefore, we must come up with reliable solutions and, in order to find them, it is important to maintain a constant dialogue between the main players: authorities, business environment and professional associations. And, at the same time, let's keep an eye on the measures that the states of the world are thinking about for the post-crisis period.

In our future research, when data will be available for the year 2020, we want to analyze the impact of COVID-19 over the economic sectors which were the most affected. Therefore, we will be able to determine exactly the results of the measures adopted by EU Member States and 
we will be able to evaluate their effectiveness. In other words, I believe that due to the COVID-19 epidemic and the constraints it has imposed, there will be a series of structural changes in consumer behavior and in companies'business models.

\section{Acknowledgement}

This work was cofinanced from the European Social Fund through Operational Programme Human Capital 2014-2020, project number POCU/380/6/13/125015 "Development of entrepreneurial skills for doctoral students and postdoctoral researchers in the field of economic sciences"

\section{References}

Baldwin, R., Beatrice,Weder Di Mauro, B., "Economics in the Time of COVID-19", VoxEU CEPR Press, 2020.

Eurostat site, available at https://ec.europa.eu/eurostat/data/database.

European Commission site, available at: https://ec.europa.eu/.

Fornaro, L., Martin, W., "Covid-19 Coronavirus and Macroeconomic Policy", Tech-nical Report, CEPR March 2020.

Gourinchas, P. O., "Flattening the Pandemic and Recession Curves," 2020, UC Berkeley University.

Guerrieri, V., Lorenzoni, G., Straub, L., Werning, I., "Macroeconomic Implications of COVID-19: Can Negative Supply Shocks Cause Demand Shortgages?", National Bureau of Economic Research, Cambridge, April 2020.

Lee, J. W., McKibbin, W., "Estimating the Global Economic Costs of SARS" in S. Knobler, A. Mahmoud, S. Lemon, A. Mack, L. Sivitz, and K. Oberholtzer (Editors), Learning from SARS: Preparing for the next Outbreak, The National Academies Press, Washington DC (0-30909154-3),2004.

Levine, D.I.,McKibbin, W. J., "Simple steps to reduce the odds of a global catastrophe" The Brookings Institution, 2020, https://www.brookings.edu/opinions/simple-steps-to-reduce-theodds-of-a-global-catastrophe/.

McKibbin W., Sidorenko, A., "What a Flu Pandemic Could Cost the World", Foreign Policy, April 2009, https://foreignpolicy.com/2009/04/28/what-a-flu-pandemic-could-cost-the-world/

OECD (2020) http://www.oecd.org/newsroom/global-economy-faces-gravest-threat-since-thecrisis-as-coronavirus-spreads.htm.

World Health Organization, Report from 21 June 2020. 